VIII. REPORTING AND MANAGEMENT OF DATA 
[RADIOCARBON, VOL. 28, No. 2A, 1986, P 765-775]

\title{
STANDARDIZING PROCEDURES FOR COLLECTING, SUBMITTING, RECORDING, AND REPORTING RADIOCARBON SAMPLES
}

\author{
RENEE KRA \\ Radiocarbon, Yale University, New Haven, Connecticut
}

\begin{abstract}
A new radiocarbon sample record form has been compiled for consensus among radiocarbon daters and users. The form is designed to obtain comprehensive standardized documentation of radiocarbon dates for reporting and disseminating valuable data. This method of reporting ${ }^{14} \mathrm{C}$ dates will help resolve problems which include: 1) publication of all dated samples, 2) selection of significant samples, 3) interpretation of data, 4) recognition of dated samples, 2) selection of significant samples, 3) interpretation of data, 4) recognition of
problematic dates, 5) maintenance of an active archive of ${ }^{4} \mathrm{C}$ dates, and 6) implementation of an international retrieval system for dates.
\end{abstract}

A new radiocarbon sample record form was distributed to representatives of active radiocarbon laboratories and other researchers present at the Twelfth International Radiocarbon Conference. The record form was presented for consensus among the radiocarbon community. It has been designed to obtain comprehensive, standardized documentation of radiocarbon dates which can be subsequently used for date lists, publication in Radiocarbon, and, ultimately, inclusion in a radiocarbon data base.

In November 1983, I undertook a survey of ${ }^{14} \mathrm{C}$ dating sample information. I requested a copy of the form used when a sample is submitted from all active radiocarbon laboratories. I received 56 responses from 115 laboratories-or exactly a $50 \%$ return.

Using these forms as a basic framework, I compiled what I believe to be a fairly comprehensive sample record form. It is not very different from some of the extant data sheets that are in current use. I selected the most pertinent questions from these, added some new features, and with this melange, came up with a "master" form which covers almost all likely requirements for information. The goal is to acquire the most accurate and detailed information for subsequent publication and dissemination to users of ${ }^{14} \mathrm{C}$ dates. The more exhaustive the questions are, the more valuable the data will be.

Radiocarbon daters and users are well aware of the mounting problems in the field ever since ${ }^{14} \mathrm{C}$ dating began ca 35 years ago. These problems have been increasing in proportion to the number of samples being dated. With the advent of AMS dating, the number of samples being dated continues to escalate dramatically.

The source of problems in ${ }^{4} \mathrm{C}$ dating can often be found at the very beginning of the process, that is, with the sample, itself. First, there may be the possibility of environmental contamination, graduating to chemical contamination during collection, packaging, and storage. Insufficient sample size, laboratory equipment failure, and even human error, are a few more examples of error sources. Problems with dates are not always recognized immediately. Therefore, it is not enough to publish ${ }^{14} \mathrm{C}$ dates on a regular basis; we also have to re-evaluate the work that has already been done, particularly from the beginning stages of radiocarbon dating. An 
excellent example of this type of re-assessment of previous research appears in an article by James Weinstein (1984).

Perhaps the most generalized dilemma shared by ${ }^{14} \mathrm{C}$ daters is the back$\log$ of processed samples which remain unreported. A complaint that I have heard often is lack of time or data available to compile worthwhile date lists, especially those crammed with interpretative commentary from cooperative submitters.

Samples are often submitted and dated without significant reason for doing so. For example, a single date from an undistinguished context will not hold much value. The submitting researcher should know what it is that he or she wants to learn from the date and this goal should be evaluated by the laboratory before the sample is processed.

When reported, the value of the date should be clearly stated in terms of associated material, provenience, comparative data, or a specific event, such as climatic or cultural change. The date should be described and interpreted and complementary references provided. The most recent calibration data (eg, Becker \& Kromer, 1986; de Jong, Becker \& Mook, 1986; Klein et al, 1982; Kromer et al, 1986; Linick et al, 1986; Pearson et al, 1986; Stuiver, 1982; Stuiver et al, 1986) should be used in the adjustment of age ranges. The calibrated dates should be reported as "cal BP" or "cal AD/BC.", Dates should also be rounded off according to Stuiver and Polach (1977).

The journal, Radiocarbon, should be an archive for all ${ }^{14} \mathrm{C}$ dates. It was, indeed, founded with that intent. In actuality, however, a minimum of dates are published. Out of 115 active laboratories, an average of 20 laboratories per year publish date lists in Radiocarbon. ${ }^{14} \mathrm{C}$ dates are reported in many other publications, but one archive dedicated to ${ }^{14} \mathrm{C}$ dates would make information infinitely more accessible to and less time-consuming for users.

With centralized, standardized data available, an international retrieval system can be implemented by means of a computerized ${ }^{14} \mathrm{C}$ data base. A workshop to implement this plan was held at this conference.

The proposed ${ }^{14} \mathrm{C}$ sampling record starts with a brief description of collection, packaging, submitting, and reporting samples. For the most authoritative account on collection and submission of samples, see a booklet written by Polach, Golson, and Head (1980).

A few important features of the record form should be noted.

1) In most cases, each sample is to be recorded on a separate form. There are instances, however, when a submitter feels confident that more than one sample from an undifferentiated context will date a single event. In such a case, a single form can be used for multiple samples, the number of which should be left to the discretion of the submitter. One form may also be used for a single series or profile.

2) After the sample has been dated, calibrated date ranges should be added routinely to the data for each sample.

3) A full description of the site is called for, including the physical, climatic, and vegetational nature of the site, illustrated by a map.

4) A full description of the sample should be given, including its material, condition, provenience, collection techniques, contamination possibil- 
ities, and temporal associations based on geologic or archaeologic estimates, related finds, or previous research. Horizontal and vertical grids are provided for graphic visualization of the sample in its context.

5) Full referencing of relevant published and unpublished material must be recorded as well as future plans for publication.

6) After the sample has been dated, a full account of the value of the date should be provided by the submitter.

7) The submitter is asked to provide additional pertinent information on the sample and site, such as photographs, maps, pollen diagrams, or particular observations.

The ${ }^{14} \mathrm{C}$ sample record form has been conceived as a service to ${ }^{14} \mathrm{C}$ daters and users. If adopted in its present or near-present form, it should help to upgrade our standards for recording, evaluating, and reporting ${ }^{14} \mathrm{C}$ dates. It should also facilitate publication and dissemination of these valuable data. Although not designed for specialized categories of ${ }^{14} \mathrm{C}$ dating, such as groundwater, ice core, and ocean sampling, the record form should lend itself to the main body of ${ }^{14} \mathrm{C}$ dating.

Since the format and content of this record form should suit the needs of ${ }^{14} \mathrm{C}$ daters and users, the author would appreciate comments and suggestions from readers. Useful comments made by participants at the conference have been incorporated into the revised form that follows. The principal criticism seems to be that it is too long and detailed. My answer is that it is better to ask for more and get less than not to ask at all. The more information provided, the better the interpretation of the results and the published material will be.

\section{ACKNOWLEDGMENTS}

I would like to gratefully acknowledge the cooperation of the 56 laboratory directors who provided their sample record forms for use in the compilation of the present form. I also thank Andrew Moore, Yale University, Steven Porter, University of Washington, Irving Rouse, Yale University, and James Weinstein, Cornell University, for their helpful advice. I am particularly grateful to Roger Moeller, editor of North American Archaeologist, for his encouragement and technical assistance. Thanks also go to Lucianne Lavin, Yale University, for being the first submitter to use this form, and Minze Stuiver, University of Washington, for being the first radiocarbon dater to work with this form. 


\section{RADIOCARBON SAMPLING RECORD}

\section{Collection of Samples}

Radiocarbon dating of samples is carried out by a measurement of the original carbon atoms in the sample at the time it was removed from the life cycle. Organic sample materials, such as charcoal, wood, peat, etc, are most suitable for dating. The extremely porous nature and low carbon content of bone allows ground water to alter the bone age. The many problems associated with shell-marine, freshwater, or terrestrial-can very broadly be described as environmental contamination.

For an accurate age determination, it is essential that the sample is not contaminated by extraneous carbon atoms during collection and packing. Grease, oil, packing material, human hair, brush hair, tobacco or cigarette ash, for example, can cause contamination if inadvertently mixed with a sample.

Environmental interaction as well as cleaning, pretreatment, and processing reduce the size, weight, and amount of carbon-containing material in a sample. Thus, it is very important that an adequate sample size be collected. A safe rule is to collect as much sample as possible. (Preferred amounts of dry weight vary with each laboratory; thus, each laboratory should compose its own table for sample weights including: charcoal, wood, shell, bone peat, etc).

Collection should be done from an undisturbed area. Sediment samples must be collected from freshly exposed surfaces. Copious notes should be taken at the time of collection following the accompanying sample record form.

Samples should be collected with clean stainless steel scalpels and tweezers or plastic or steel scoops. Remove soil adhering to the sample at the site. Visible rootlets should also be removed by sieving or hand-picking using tweezers. No preservatives should be used on samples submitted for dating.

\section{Packing}

Sample material should be packed in aluminum foil and sealed in thick polyethylene bags or directly in polyethylene bags which, in turn, are clearly labeled (preferably with an index card). Samples must not be in direct contact with cotton, cloth, shredded paper, or other packing materials.

Each sample submitted for dating should be accompanied by one copy of the sample record form completely filled out. Duplicate forms are to be completed for each sample-one for the laboratory and one for the submitter.

For an excellent, detailed account on collection and submission of samples for radiocarbon dating, see Polach, Golson, and Head (1980).

\section{Reporting Radiocarbon Dates}

By international agreement, conventional ${ }^{14} \mathrm{C}$ ages are calculated using the Libby half-life of $5570 \pm 30$ years and 0.95 times the activity of NBS oxalic acid as the modern standard, normalized to $\delta^{13} \mathrm{C}=-19 \%$. Results which reflect the post $\mathrm{AD} 1955$ rise in atmospheric ${ }^{14} \mathrm{C}$ (due to nuclear weapons testing) are reported as ratios of the modern standard value. 
Ages BP are ${ }^{14} \mathrm{C}$ years before AD 1950 and the statistical uncertainty is one standard deviation $(1 \sigma)$. The designation, $\mathrm{AD} / \mathrm{BC}$, is discontinued in Radiocarbon. Calendar-estimated ages may be included as a comment along with citation of the calibration curve used. Calibrated dates are now reported as "cal BP" or "cal $\mathrm{AD} / \mathrm{BC}$ " according to the consensus of the Twelfth International Radiocarbon Conference, Trondheim, Norway, 1985. (See Becker \& Kromer, 1986; de Jong, Becker \& Mook, 1986; Klein et al, 1982; Kromer et al, 1986; Linick et al, 1986; Pearson et al, 1986; Pearson \& Stuiver, 1986; Stuiver, 1982; Stuiver et al, 1986; Stuiver \& Pearson, 1986; Vogel et al, 1986.)

Both dates and standard errors are rounded off according to Stuiver and Polach (1977). All measurements should be reported in SI (metric units). For preparation of manuscripts for publication in Radiocarbon, see Kra (1984). For an excellent model of current re-evaluation of previous research, see Weinstein (1984).

\section{REFERENCES}

Becker, B and Kromer, B, 1986, Extension of the Holocene dendrochronology by Preboreal pine series, 8800 to $10,100 \mathrm{BP}$, in Stuiver, M, and Kra, R S, eds, Internatl ${ }^{14} \mathrm{C}$ conf, $12 \mathrm{th}$, Proc: Radiocarbon, v 28, no. $2 \mathrm{~B}$.

Jong, A F M de, Becker, B and Mook, W G, 1986, High-precision calibration of the radiocarbon time scale: 3930-3230 cal BC, in Stuiver, M and Kra, R S, eds, Internatl ${ }^{14} \mathrm{C}$ conf, 12th, Proc: Radiocarbon, v 28, no. $2 \mathrm{~B}$.

Klein, J, Lerman, J C, Damon, P E and Ralph, E K, 1982, Calibration of radiocarbon dates: tables based on the consensus data of the Workshop on Calibrating the Radiocarbon Time Scale: Radiocarbon, v 24, p 103-150.

Kra, R S, ed, 1984, Radiocarbon Style Guide: Radiocarbon, v 26, p 152-158.

Kromer, B, Rhein, M, Bruns, M, Schoch-Fischer, H, Munnich, K O, Stuiver, M and Becker, B, $1986,{ }^{14} \mathrm{C}$ calibration data for the 6 th to the 8 th millennium BC, in Stuiver, $\mathrm{M}$ and Kra, $\mathrm{R} \mathrm{S}$, eds, Internatl ${ }^{14} \mathrm{C}$ conf, 12 th, Proc: Radiocarbon, v 28, no. $2 \mathrm{~B}$.

Linick, T W, Long, A, Damon, P E and Ferguson, C W, 1986, High-precision ${ }^{14} \mathrm{C}$ dating of bristlecone pine from $6550-5350 \mathrm{BC}$, in Stuiver, $\mathrm{M}$ and Kra, R S, eds, Internatl ${ }^{14} \mathrm{C}$ conf, 12th, Proc: Radiocarbon, v 28, no. 2B.

Pearson, G W, Pilcher, J R, Baillie, M G, Corbett, D M and Qua, F, 1986, High-precision ${ }^{14} \mathrm{C}$ measurements of Irish oaks to show the natural ${ }^{14} \mathrm{C}$ variation from $5200 \mathrm{BC}$ to AD 1840 , in Stuiver, $\mathrm{M}$ and $\mathrm{Kra}, \mathrm{R} \mathrm{S}$, eds, Internatl ${ }^{14} \mathrm{C}$ conf, 12 th, Proc: Radiocarbon, v 28, no. $2 \mathrm{~B}$.

Pearson, G W and Stuiver, M, 1986, High-precision calibration of the radiocarbon time scale $500 \mathrm{BC}-2500 \mathrm{BC}$, in Stuiver, $\mathrm{M}$ and $\mathrm{Kra}, \mathrm{R} \mathrm{S}$, eds, Internatl ${ }^{14} \mathrm{C}$ conf, 12 th, Proc: Radiocarbon, v 28, no. $2 \mathrm{~B}$.

Polach, H, Golson, J and Head, J, 1980, Radiocarbon dating: a guide for archaeologists on collection and submission of samples and age reporting practices: Preprint, Canberra, Australian Inst Aboriginal Studies.

Stuiver, M, 1982, A high-precision calibration of the AD radiocarbon time scale: Radiocarbon, v 24, p 1-26.

Stuiver, M, Kromer, B, Becker, B and Ferguson, C W, 1986, Radiocarbon age calibration back to 13,300 years BP and the ${ }^{14} \mathrm{C}$ age matching of the German oak and US bristlecone pine chronologies, in Stuiver, $\mathrm{M}$ and Kra, R S, eds, Internatl ${ }^{14} \mathrm{C}$ conf, 12 th, Proc: Radiocarbon, v 28, no. $2 \mathrm{~B}$.

Stuiver, M and Pearson, G W, 1986, High-precision calibration of the radiocarbon time scale, AD 1950-500 BC, in Stuiver, M and Kra, R S, eds, Internatl ${ }^{14} \mathrm{C}$ conf, 12 th, Proc: Radiocarbon, v 28, no. $2 \mathrm{~B}$. Stuiver, $\mathrm{M}$ and Polach, H A, 1977, Discussion: Reporting of ${ }^{14} \mathrm{C}$ dates: Radiocarbon, v 19, $\mathrm{P}$
355-363.

Vogel, J C, Fuls, A, Visser, E and Becker, B, 1986, Radiocarbon fluctuations during the third millennium BC, in Stuiver, $\mathrm{M}$ and Kra, R S, eds, Internatl ${ }^{14} \mathrm{C}$ conf, 12 th, Proc: Radiocarbon, $\mathrm{2} 28$, no. $2 \mathrm{~B}$.

Weinstein, J M, 1984, Radiocarbon dating in the southern Levant: Radiocarbon, v 26, p 297366. 


\section{RADIOCARBON SAMPLING RECORD \\ USE ONE FORM PER SAMPLE, SERIES, OR PROFILE}

\section{RADIOCARBON LABORATORY ADDRESS}

All items on this sample record form must be filled in. A sample will not be processed before this form is completed! Do not leave blank spaces; if a question does not apply to your sample, state as much. Attach additional sheets if necessary. The more information you provide, the better the interpretation of the results and the published material will be.

Submitter:

Address:

(Institution)

Telephone:

(Home)

Collector:

Address:

Affiliation:

Geographic location of site-Country:

State:

District:

Village/Town:

Site name/number:

\section{FOR LAB USE ONLY}

\section{SAMPLE NO.:}

Received and acknowledged:

Date

Sponsor:

Special instructions:

Acceptance: Date

Rejection: Date

Reason:

Measurement started: Date

Result reported: Age of sample

Age BP: $\quad \Delta^{14} \mathrm{C}$ :

$\delta^{13} \mathrm{C}: \quad$ Other:

Calibrated date range:

Calibration curve used:

For Date List No.:

Date of submission:

(Office)

Date collected:

Telephone:

Collector/submitter id. no.:

Province:

County:

Other: 
Geographic coordinates or equivalent:

Latitude:

Longitude:

Other:

Altitude:

Description of site (climatic, vegetational [past and present], geologic, distance from nearest town, associated water courses, other landmarks, primary or secondary). Provide full description and sketch map of site location in space provided:

DESCRIPTION OF SITE MAP OF SITE

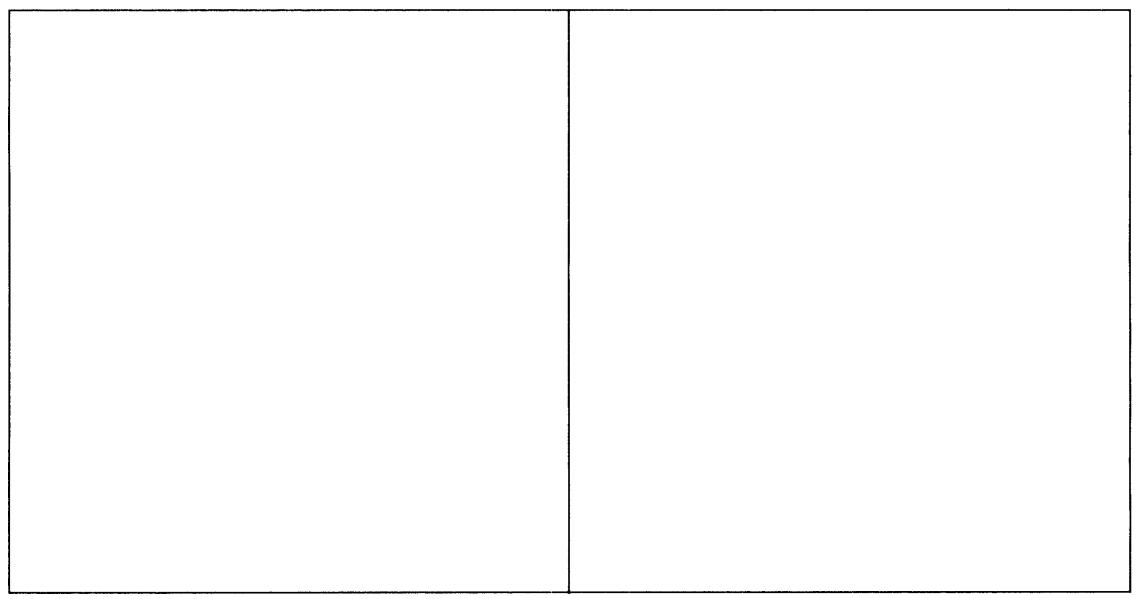

Field of study (archaeology, palynology, geology, oceanography, geochemistry, hydrology, soils, volcanoes, glaciers, limnology, other):

Sample material (charcoal, wood, plant, bone, water, peat, shell [marine, freshwater, terrestrial], lake sediment, soil, carbonate, tufa, animal tissue, tree trunk, other):

Description of material:

Concentrated or fragmented structure:

Species identification (scientific name): (popular name):

Part of series or profile? If so, total number of samples submitted: 
Depth (below surface, water level, sediment, other):

Weight:

Condition of sample (wet, dry, damp, oven-dried, root-penetrated, covered with fungus, crushed, decayed, other):

Context or provenience of sample:

If archaeologic (dwelling, grave, cave, hearth, feature, artifact, workshop, shell midden, special activity site, open-air station, other):

If geologic, (bog, glacial, marine, silt, gravel, other):

\author{
Stratigraphy: \\ Trench or pit number: \\ Layer or level number or both: \\ Location in excavation site: \\ Under/overlying levels: \\ Soil horizon: \\ Matrix material of layer:
}

Chemical environment (limestone, hard/soft water, dry, continuously submerged, exposed to elements, seasonal flooding, other):

Sample collection from (excavation, exposed surface, eroded area, road cut, stream cut, other):

If exposed, for what period?

How was sample collected? (give details, including tools used):

How was sample treated? (hand-picked, roots removed, air-dried, other):

Packaging details:

Storage details:

Possible sources of contamination (groundwater percolation, animal burrows, humic acid, intrusive rootlets, carbonates, fungicides or preservatives used in storage or packing, recycled wood, fungal growth, flooding, limestone water-logging, hard water, other): 


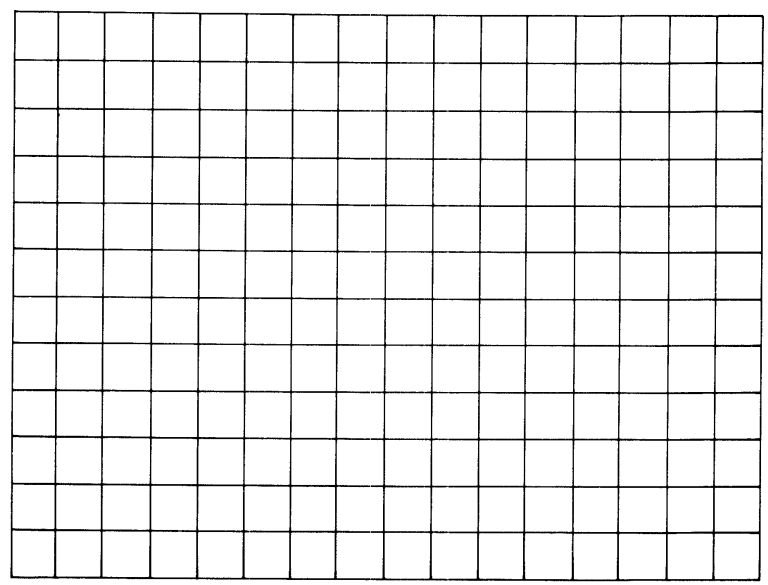

HORIZONTAL. Diagram the horizontal position of the sample on the grid above including distance over which sample was collected, dimensions of the site area, and associated finds. Provide scale.

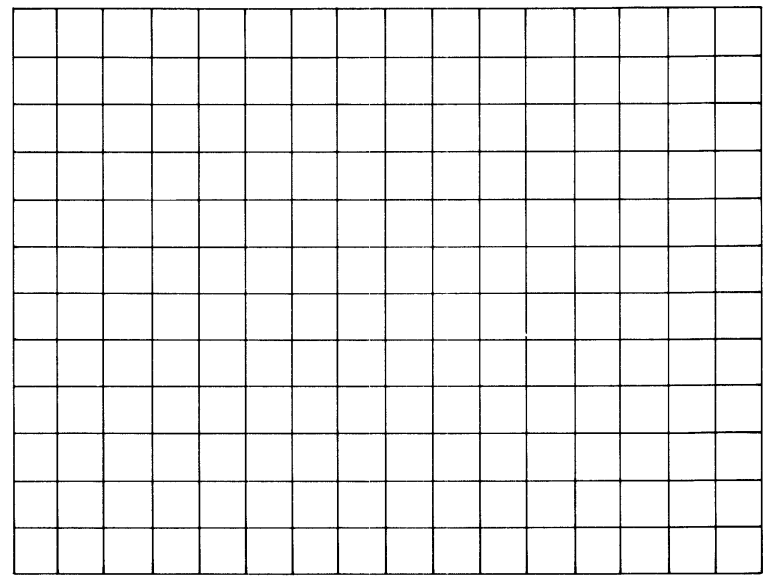

VERTICAL. Diagram the vertical position of the sample on the grid above, including thicknesses and composition of over/underlying strata, depth of sample in situ, relation to associated finds in the same or adjacent horizons, and depth of visible root penetration, water levels, or other occurrences. Provide scale. 
If sample is geologic, where does it fit in, in terms of: glacial or interglacial period:

pollen diagram:

dendrochonology:

soil development:

bog development:

climatic phase:

beach emergence:

other:

If sample is archaeologic, what is its assumed cultural affiliation, in terms of:

component or occupation:

phase or focus:

complex, industry, or style:

tradition or horizon:

stage:

series:

other:

Does sample date a particular event?

What are the dates, if any, of associated material? List all other dates, ${ }^{14} \mathrm{C}$ or other method, pertinent to this sample, from the same or similar site(s). Cite lab nos. and publication wherever possible:

Estimated age before dating: From: To:

Basis of estimate (style, associated finds, stratigraphy, etc):

Purpose of dating this sample: 


\section{REFERENCES}

Cite publications or relevant unpublished material that would be useful to the interpretation of these findings. It is extremely important that comprehensive information be provided on the relevance of this date. Manuscripts in preparation, in press, on file, and $\mathrm{PhD}$ dissertations should be included. Use the space provided below for a minimum of references, affix an additional sheet for more references. Use the reference style of Radiocarbon including author, year, title, journal, volume, number, and inclusive pagination.

Do you have plans for future publication or research related to this sample? Give full details.

On a separate sheet(s) please provide additional pertinent information about this sample (eg, maps, photographs, drawings, pollen diagrams). Also provide notes of any particular observations or exceptional factors concerning this sample.

\section{LABORATORY COMMENTS AND PROCEDURE SHEET FOR LABORATORY USE ONLY}

This should be a separate sheet that is used at each laboratory. It should be formatted to suit the particular needs of the laboratory.

\section{AFTER DATING}

Value of results:

Does this date agree or disagree with your expectations for this sample?

If not, what do you think is the reason for its anomalous age?

Other variables affecting the validity of the date?

Provide a full comment as you would like it to appear in Radiocarbon. Be precise and concise but give full and pertinent data. Provide identification, initials, and association of commentator if other than submitter. Affix additional sheets, if necessary. 